\title{
OBTAINING ENVIRONMENTALLY SAFE MIXED FERTILIZERS CONTAINING TRACE ELEMENTS BASED ON CARBONATE-SILICEOUS DOLOMITIZED PHOSPHATE RAW MATERIALS AND WASTES CHP
}

\author{
K.T. Zhantasov ${ }^{1}$, A. M. Kozhakhmetova ${ }^{1, \bowtie}$, O. B. Dormeshkin ${ }^{2}$, \\ N. K. Sarypbekova ${ }^{3}$, M. K. Zhantasov ${ }^{4}$, O. P. Baiysbay ${ }^{5}$ and A. M. Dosbayeva ${ }^{6}$ \\ ${ }^{1}$ M. Auezov South Kazakhstan University/ Department of Chemical Technology of inorganic \\ substances, Tauke Khan av. 5, Shymkent, Kazakhstan \\ ${ }^{2}$ Belarusian State Technological University / Department "Technology of inorganic substances \\ and general chemical technology", Sverdlova street 13A Minsk BY, 220006, Belarus \\ ${ }^{3}$ M. Auezov South Kazakhstan University/ Chemistry and Foundations of Chemical Technology, \\ Tauke Khan av. 5, Shymkent, Kazakhstan \\ ${ }^{4}$ M. Auezov South Kazakhstan University/ Oil and Gas Business, Tauke Khan av. 5, \\ Shymkent, Kazakhstan \\ ${ }^{5}$ M. Auezov South Kazakhstan University/ Department of Mechanic and engineer, Tauke Khan \\ av. 5, Shymkent, Kazakhstan \\ ${ }^{6}$ M. Auezov South Kazakhstan University/ Department of Ecology, Tauke Khan av. 5, \\ Shymkent, Kazakhstan \\ ${ }^{\square}$ Corresponding Author: aydanak89@bk.ru
}

\begin{abstract}
The article provides information about the environmental impact of man-made waste generated in industrial regions. Mineralogical and chemical properties of technogenic wastes of industrial regions, in particular, waste of coal mining, mining and industrial complex of phosphate and siliceous raw materials extraction in the Karatau phosphorite basin of the Republic of Kazakhstan are presented. The data on the chemical and mineralogical composition of ash and slag waste generated by the combustion of coal from the Karaganda and Ekibastuz basins are presented. The results of differential thermal and X-ray analyses of carbonate - siliceous dolomitized phosphate raw materials of the Aksai Deposit and its chemical composition are shown. The results of analyses of brown and hard coal ash from the Ekibastuz and Karaganda basins are presented. In addition, the reflectivity of ash formed after burning coal from the Bogatyr section of the Ekibastuz basin, as well as its physical and chemical properties and characteristics for macro and microelements, is given.

Keywords: Fertilizer Mixtures, Mineral Fertilizers, Carbonate-siliceous phosphate-dolomitized Raw Materials, Ash and Slag Waste, Thermal Power Plants, Screening of Dolomite Ores, Macronutrients, Trace.

RASĀYAN J. Chem., Vol. 14, No.2, 2021
\end{abstract}

\section{INTRODUCTION}

In the current world and domestic markets, today's situation makes mineral fertilizers and mixed fertilizers several technological and technical requirements. Therefore, the production of high-quality products of the chemical sub-sector and the agro-industrial complex is relevant. This fact is the basis for research on the development and creation of environmentally safe fertilizer mixtures from off-balance carbonate-siliceous dolomitized phosphate raw materials and waste heat and power centers (CHP).

The use of mineral fertilizers is one of the most important methods of increasing the productivity of agricultural sectors and, in particular, supporting macro-and microelements in fertile soil. However, the use of fertilizers and fertilizer mixtures in market conditions requires the development of new methods 
and methods of production, as well as ways of applying them to the soil, providing the maximum effect obtained from each kilogram of the active substance.

The world industry the production of mineral fertilizers has several characteristic features:

- Dependence of fertilizer production on the supply of raw materials and fuel and energy resources;

- Significant capital intensity of the enterprise under construction;

- The need to concentrate production near sources of raw materials;

- Construction of an enterprise with a large unit capacity, to reduce the cost of production per unit of finished products;

- A significant share of exports of various types of fertilizers and fertilizer mixtures in the volume of their global production, due to the uneven distribution of natural resources in countries and regions of the globe.

It is well known that the centers of production of phosphorus and nitrogen fertilizers are located in the areas of consumption, and potash-in the areas of extraction of raw materials. Today, the largest producers of nitrogen and phosphorus-containing fertilizers are regions and consumer countries, such as China, India and the United States, and producers of potassium-containing fertilizers are Canada, Russia and Belarus, which have potash raw materials. ${ }^{1}$

Production of mineral fertilizers, high concentration of the raw materials used is evidenced by the fact that 15 countries account for almost $80 \%$ of the volume of ammonia upon receipt of nitric fertilizers and $85 \%$ of production volume of production Froude located in 7 countries, and 6 countries produced more than $85 \%$ of potassium chloride. ${ }^{2,3}$

From an ecological point of view, the ash dumps of the CHPP create great ecological tension in the industrial regions, creating a threat to the environment and human health. As a result of wind erosion, ash particles containing settled dust and chemically active toxic substances spread over several kilometers, polluting the soil, water and atmosphere. ${ }^{3}$

\section{EXPERIMENTAL}

The main type of fuel and energy resources of Kazakhstan is the coals of Ekibastuz and Karaganda deposits. The burning of organic fuel to produce electricity and heat is one of the foundations of the functioning of modern society and the economy of the country.

In the Republic of Kazakhstan, there are currently 32 thermal power plants running on solid fuel, which are 2-4 times more polluting the environment with radioactive substances than nuclear power plants of the same capacity.

For the implementation and application of ash and slag as raw materials, for their safe storage and use, in various sectors of the country's economy, it is necessary to have basic information on their characteristics: mineralogical composition, physical and chemical properties, radioactivity and toxicity.

The chemical composition of ash and slag waste depends on the mineral composition of the fuel, the content of which varies depending on the coal Deposit.

Many advanced modular plants can produce the following dry ash slags products with high consumer value:

- Fertilizers for agriculture and the scavengers of acidic soils based on high calcium angry coals;

- Multi-purpose ash microsphere;

- The underlying dry the bedding under the covering of highways of reinforced concrete from high calcium angry with hydration heat capacity;

- Disposable heaters for various purposes for domestic and industrial needs of the Ministry of Emergency Situations (MES);

- Dry ash-clinker and linker-free binders based on acidic, ultra-acidic and high-base ash;

- Fine and fine-, medium -, coarse-grained sand, multi-fraction crushed stone based on crushed slag;

- Dry construction and concrete mixes for various purposes.

The annual yield of ash and ash-slag mixtures in the Republic of Kazakhstan, formed during the burning of coal, is about 19-20 million tons. To date, more than 300 million tons of ash and slag waste have been 
RASĀYAN J. Chem.

Vol. 14 | No. 2 |1208-1215| April - June | 2021

accumulated in the dumps, which contain such trace elements as iron, magnesium, manganese and potassium, which can be used as additives to the main phosphate raw materials, in the production of mineral fertilizers and flour mixtures. To date, the phosphorus industry is experiencing a shortage of highquality phosphate raw materials and requires selective workings.

It is well known that the main components necessary for the mineral nutrition of plants are nitrogen, phosphorus and potassium. In addition to these three basic nutrients, several other elements called trace elements are needed for the normal development of plants. They are part of a large number of natural and artificial compounds. However, for these compounds to be used as fertilizers, two basic conditions must be met:

1. Nutrients should be available in forms available to plants;

2. The content and ratio of elements must meet the physiology of plant nutrition.

High yields can be achieved by providing plants with complete and sufficient fertilizers for their nutrition. In this regard, it is necessary to expand the range of mineral fertilizers, including dry flour mixtures enriched with macro - and microelements in the form of iron, magnesium, sulfur, etc., without which plants get sick, this leads to low yields. The use of micro fertilizers provides a significant increase in yield and improves the quality of plant products, increasing their nutritional value. ${ }^{4,5}$

It should be noted that the elements contained in ash slag and off-balance carbonate-siliceous phosphorites can to some extent contribute to the stabilization of the $\mathrm{pH}$ balance of the soil that is intended for sowing. In addition, based on the analysis of its chemical composition, it is possible to determine the presence of macro-or microelements and which microelements are necessary for the soil environment. ${ }^{6}$

\section{RESULTS AND DISCUSSION}

In light of the above-conducted studies to determine the mineral and chemical compositions of offbalance carbonate-siliceous phosphate ore of Karatau basin and ash waste CHP.

Representative samples of carbonate-siliceous dolomitized phosphate raw materials of the Aksai Deposit and ash and slag waste generated during coal burning in the Ekibastuz and Karaganda coal basins were selected $^{12}$. The chemical composition of the off-balance dolomitized phosphorite of the Aksai Deposit is shown in Table-1, and the coals in Table-1.

Table-1: Chemical Composition of Off-balance dolomitized Phosphorites of the Aksai Deposit

\begin{tabular}{c|c|c|c}
\hline No. & $\begin{array}{c}\text { Name of the Defined Characteristics, } \\
\text { Unit of Measurement }\end{array}$ & $\begin{array}{c}\text { Actual Values based on } \\
\text { Test Results }\end{array}$ & Test Methods \\
\hline 1 & Mass fraction of potassium, $\%$ & 1,49 & GOST 5382-91 \\
\hline 2 & Mass fraction of calcium, $\%$ & 29,85 & GOST 4013-82 \\
\hline 3 & Mass fraction of magnesium, $\%$ & 1,72 & GOST 5382-91 \\
\hline 4 & Mass fraction of manganese, $\%$ & 0,01442 & GOST 5382-91 \\
\hline 5 & Mass fraction of phosphorus, $\%$ & 8,32 & GOST 5382-91 \\
\hline 7 & Mass fraction of fluorine, $\%$ & 0,003 & GOST 5382-91 \\
\hline
\end{tabular}

Table-2: Chemical Composition of Coal Ash by the Main Components of the Bogatyr, Karazhyr and Maikube Sections of the Ekibastuz and Karaganda Basins

\begin{tabular}{c|c|c|c|c|c|c|c|c}
\hline \multirow{2}{*}{$\begin{array}{c}\text { Coal Ash } \\
\text { Deposits }\end{array}$} & \multicolumn{7}{|c|}{ Content of the Components, \% } & \multirow{2}{*}{$\begin{array}{c}\mathrm{NH} \text { on } \\
\mathrm{KCl}\end{array}$} \\
\cline { 2 - 9 } & $\mathrm{SiO}_{2}$ & $\mathrm{Al}_{2} \mathrm{O}_{3}$ & $\mathrm{Fe}_{2} \mathrm{O}_{3}$ & $\mathrm{MgO}$ & $\mathrm{TiO}_{2}$ & $\mathrm{Na}_{2} \mathrm{O}+\mathrm{K}_{2} \mathrm{O}$ & $\mathrm{CaO}$ & \\
\hline Bogatyr & 59,7 & 24,3 & 5,2 & 1,03 & 1,13 & 0,79 & 4,9 & $7,6-8,1$ \\
\hline Karazhyr & 54,9 & 29,6 & 4,2 & 1,92 & 2,85 & 0,92 & 2,7 & 8,0 \\
\hline Maikube & 56,5 & 24,6 & 5,9 & 0,83 & 1,26 & 0,61 & 3,7 & 7,8 \\
\hline
\end{tabular}

Analysis of Table-2 shows that the total content of exchange cations of calcium and magnesium ranges from 5.5 to $42 \mathrm{mg}-\mathrm{EQ} / 100 \mathrm{~g}$ of substrate. Following the work of the author ${ }^{15}$, it is noted that the content of exchange cations in the ash of brown coals is higher than in the ash of hard coals.

Mineral-petrographic analysis under the microscope MIN8 and MIN9 found that the crushed sample is light brown, consists of dolomite, possibly the presence of calcite, Apatite, quartz, feldspar. Quantitative 
RASĀYAN J. Chem.

Vol. 14 | No. 2 |1208-1215| April - June | 2021

ratios are given in the results of x-ray phase analysis. Apatite is similar in optical constants to the one described above. Analysis under a microscope showed that the sample has a dirty brown color, not transparent, close to isotropic. The sample in the cathode rays glows orange, which is typical for carbonate minerals.

Apatite (fluorapatite) is a mineral of the hexagonal system with variable content of $\mathrm{F}, \mathrm{Cl}, \mathrm{OH}$ with a specific gravity of 3.1-3.23 $\mathrm{g} / \mathrm{cm} 3$ in phosphorite, it is present in the form of a fine-grained aggregate, forms crusts of a radially radiant structure and spherulites. Refractive indices $\mathrm{No}=1.632, \mathrm{Ne}=1.630$.

Dolomite is a mineral of the trigonal crystal system with rhombohedral crystal shape. Refractive indices $\mathrm{Nm}=1.681-1.695, \mathrm{~Np}=1.500-1.513$, and the specific gravity is $1.8-2.9 \mathrm{~g} / \mathrm{cm} 3$. In the cathode rays, the sample glows orange, which is typical for dolomite.

Ore minerals in a polished briquette are represented by pyrite, bornite, chalcocite, iron hydroxides, as shown in Fig.-1.

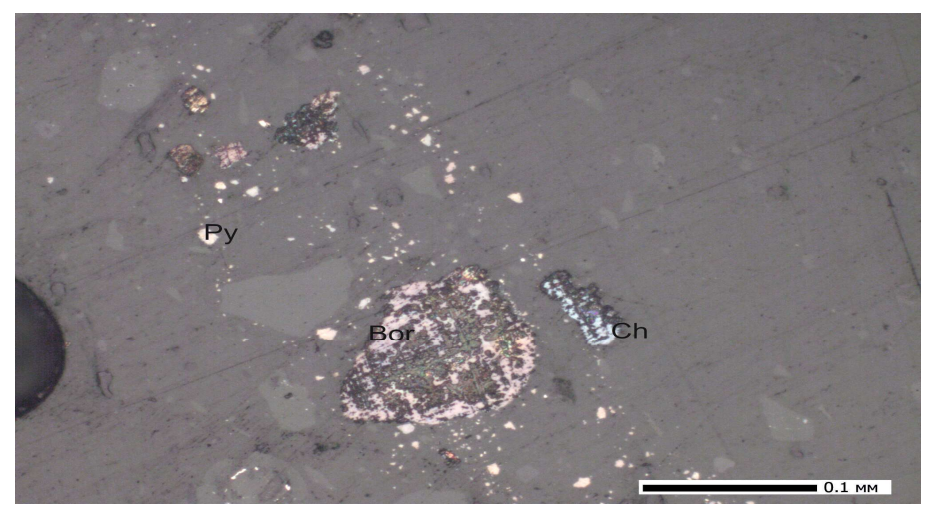

Fig.-1: Ore Minerals - Bornite, Chalcocite and Pyrite in Phosphorite

When carrying out $\mathrm{X}$ analysis of off-balance phosphate deposits of the Aksay basin Karatau ft-IR spectrometer "Avatar $370 \mathrm{CsI}$ " in the spectral range 4000-300 $\mathrm{cm}^{-1}$ in the form of tablets prepared by pressing $2 \mathrm{mg}$ of sample and $200 \mathrm{mg} \mathrm{KBr}$ using the prefix for the experiment: Transmission E. S. P. established that off-balance sheet dolomite ore consists of the following minerals:

Fluorapatite, $\mathrm{Ca}_{5}\left(\mathrm{PO}_{4}\right)_{3} \mathrm{~F}-1094,1044,965,604,577,569 \mathrm{~cm}^{-1}$

Quarz, $\mathrm{SiO}_{2}-798,779,694,515,465,397,370 \mathrm{~cm}^{-1}$

Dolomite, $\mathrm{CaMg}\left[\mathrm{CO}_{3}\right]_{2}-1455,881,729 \mathrm{~cm}^{-1}$

Dolomite, $\mathrm{CaMg}\left[\mathrm{CO}_{3}\right]_{2}-1432,881,729 \mathrm{~cm}^{-1}$

The following minerals may also be present in the sample:

Siderite, $\mathrm{FeCO}_{3}-1432,865 \mathrm{~cm}^{-1}$;

Albite, $\mathrm{Na}\left[\mathrm{AlSi}_{3} \mathrm{O}_{8}\right]-1164,648,465,430 \mathrm{~cm}^{-1}[8-11]$.

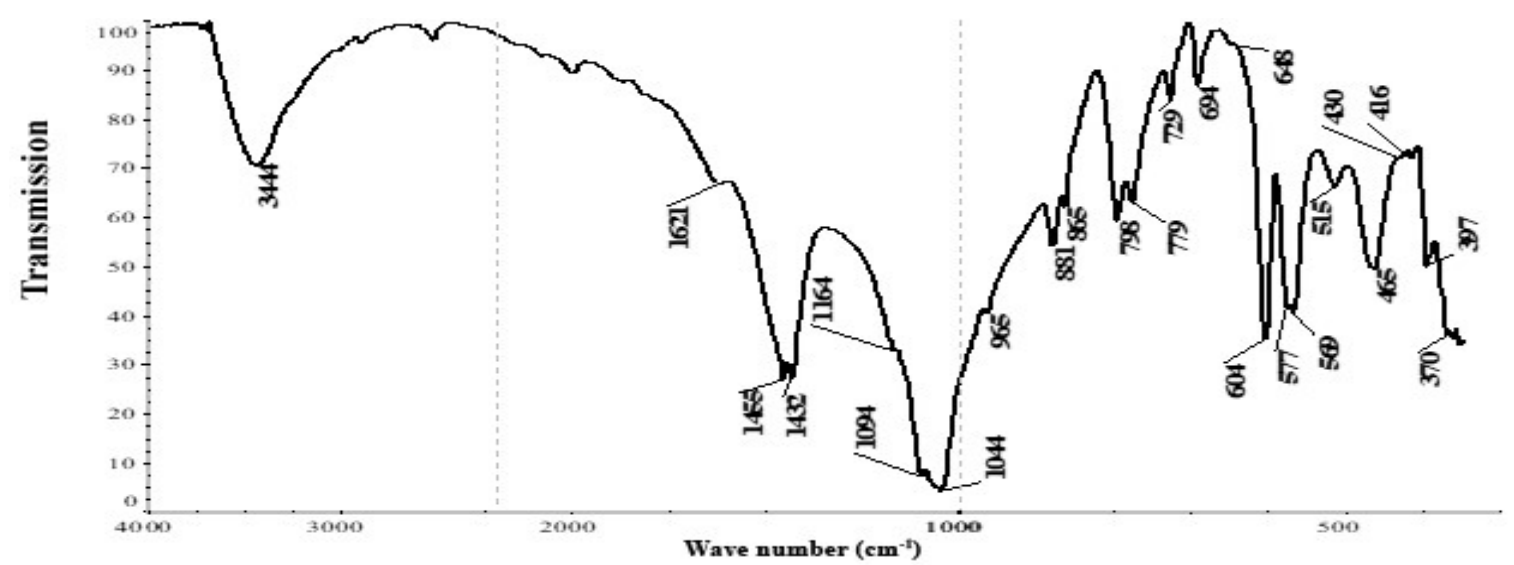

Fig.-2: Infrared Spectrum of Off-balance Carbonate-siliceous phosphate dolomitized Raw Materials of the Aksai Deposit

1211 
RASĀYAN J. Chem.

Vol. 14 | No. 2 |1208-1215| April - June | 2021

The studies were carried out on a D8 Advance (Bruker) diffractometer, $\alpha-\mathrm{Cu}$, at a tube voltage of $40 \mathrm{kV}$, a current of $40 \mathrm{~mA}$. The obtained diffract gram data were processed and interplane distances were calculated using EVA software. Analyses have established that the studied carbonate-siliceous phosphate raw materials contain (in \%):

Carbonate-fluorapatite (NR) Ca 9.55, $\left(\mathrm{PO}_{4}\right) 4.96 \mathrm{~F}_{1} .96\left(\mathrm{CO}_{3}\right) 1.283$

Quartz, $\mathrm{SiO}_{2}-65,75$

Dolomite, $\mathrm{CaMg}\left(\mathrm{CO}_{3}\right)_{2}-13,98$

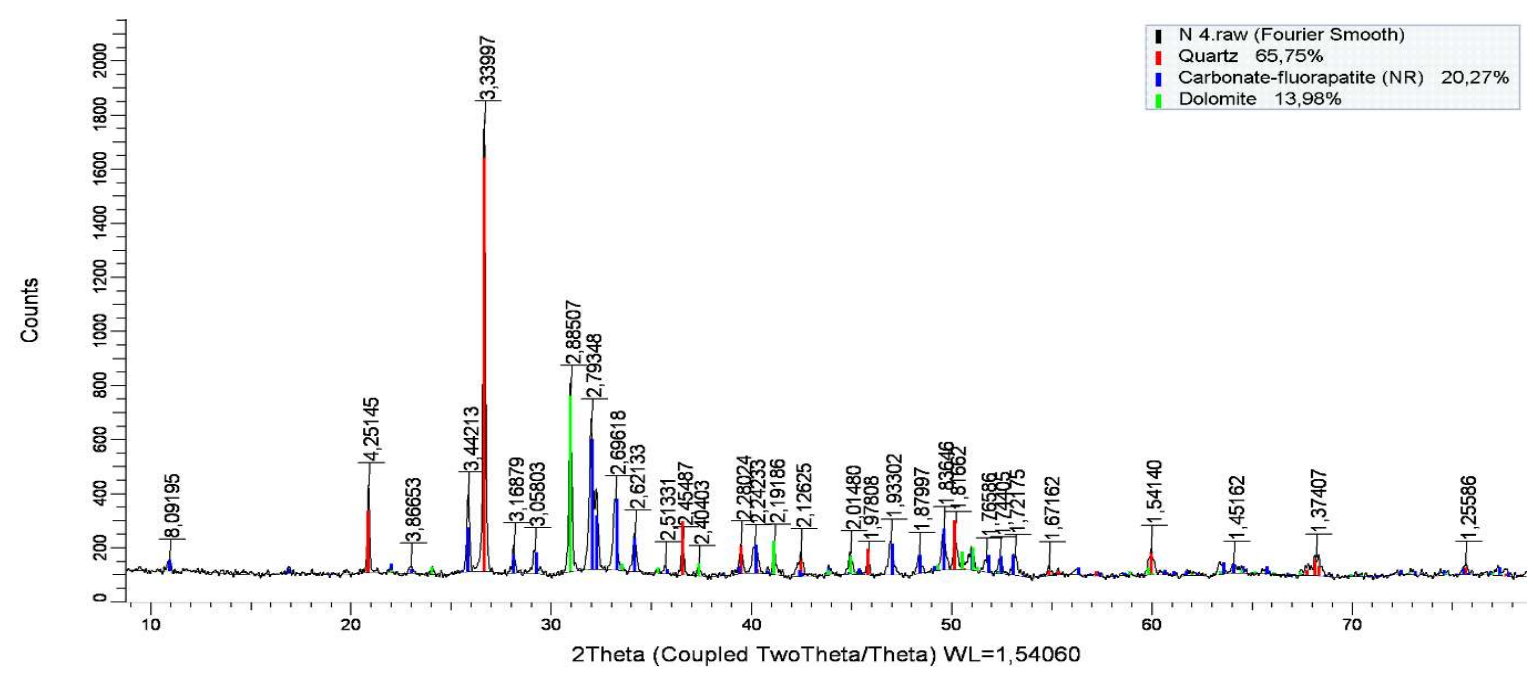

Fig.-3: X-ray Phase Analysis of Carbonate-siliceous phosphate dolomitized Raw Materials of the Aksai Deposit

Differential - thermal analysis of off-balance carbonate-siliceous dolomitized phosphorites raw materials was carried out on the Paulik-Paulik derivatograph, Erdey (IOM, Hungary), the results of which are shown in Fig.-3.

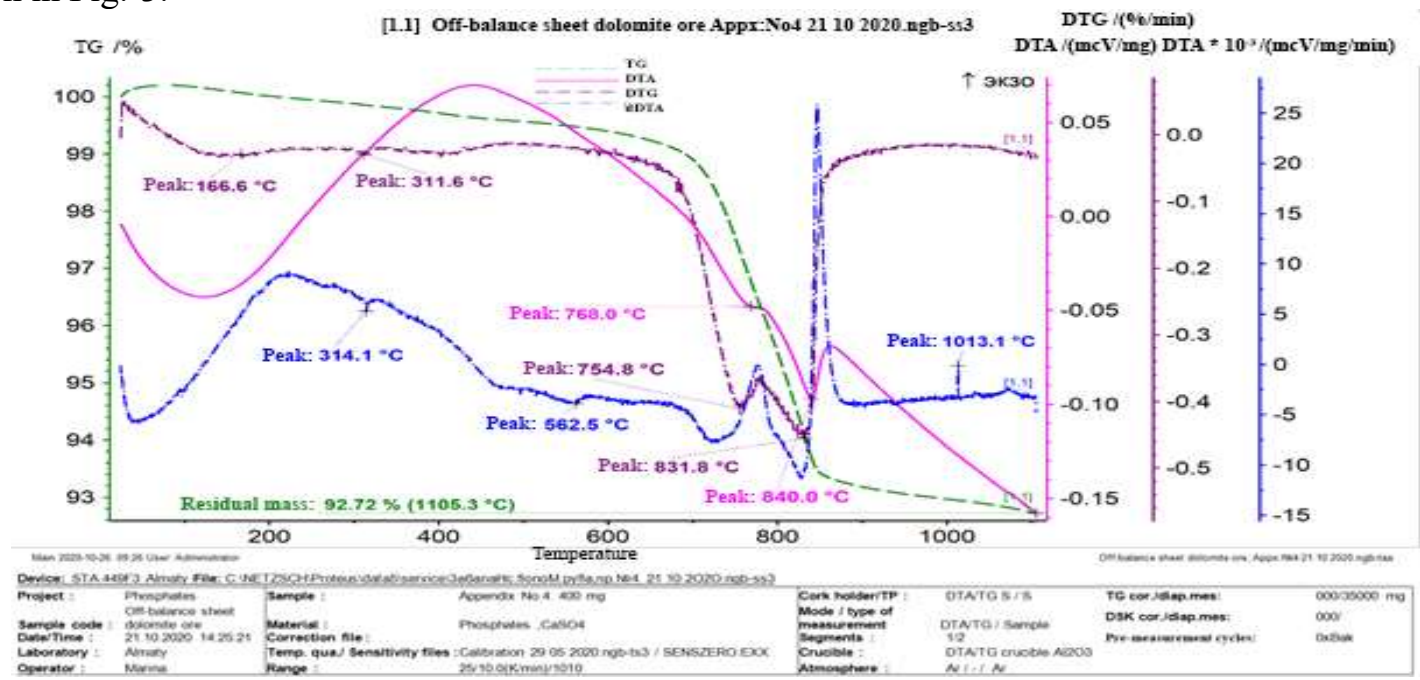

Fig.-4: Differential Thermal Analysis of Carbonate-siliceous phosphate dolomitized Raw Materials of the Aksai Deposit

The DTA curve showed in Fig. 4 shows endothermic effects with maximum development at $768^{\circ} \mathrm{C}$ and $840^{\circ} \mathrm{C}$. Additional endothermic effects were recorded on the DDT curve and their extremes were observed at $314.1^{\circ} \mathrm{C}, 562.5^{\circ} \mathrm{C}$. An exothermic effect with a peak at $1013.1^{\circ} \mathrm{C}$ was also recorded. The DTG curve shows lows at $166.6^{\circ} \mathrm{C}, 311.60 \mathrm{~S}, 754.8^{\circ} \mathrm{C}$, and $831.8^{\circ} \mathrm{C}$. 
RASĀYAN J. Chem.

Vol. 14 | No. 2 |1208-1215| April - June | 2021

Based on this, we can assume the presence of only carbonatapatite (dallite) $\mathrm{Ca}_{10}\left[\mathrm{PO}_{4}\right]_{6} \mathrm{CO}_{3}$. Its manifestation is to some extent marked by an endothermic effect with an extremum at $768^{\circ} \mathrm{C}$. The combination of the endothermic effect with an extremum at $768^{\circ} \mathrm{C}$ and the endothermic effect with an extremum at $840^{\circ} \mathrm{C}$ on the DTA curve can be assumed as a manifestation of dolomite. In addition, the presence of calcite in the overlay is not excluded, (effect $840^{\circ} \mathrm{C}$, on the DTA curve). Weak endothermic effect with an extremum at $314.1^{\circ} \mathrm{C}$ on the DDT curve, which corresponds to a minimum at $311.6^{\circ} \mathrm{C}$ on the DTH curve, which is detected due to the dehydration of iron hydroxide impurities. A weak endothermic effect with an extremum at $562.5^{\circ} \mathrm{C}$ on the DDT curve is characterized by the manifestation of quartz inversion. In addition, it is also possible to transfer $\mathrm{AlPO}_{4}$ to a tridimite-like form. The combination of a minimum at $166.6^{\circ} \mathrm{C}$ on the DTG curve and a weak exothermic effect with a peak at $1013.1^{\circ} \mathrm{C}$ on the dDTA curve reflects the presence of a small number of phosphates in the form of $\mathrm{Al}_{3}$ $\left[\mathrm{PO}_{4}\right](\mathrm{OH})_{6} 6 \mathrm{H}_{2} \mathrm{O}$.

In addition, studies were conducted to establish the physical and chemical properties of coal ash from the Ekibastuz (Bogatyr quarry) and Karaganda basin deposits.

Figure-5 shows the results of the mineral-petrographic analysis of the ash of Ekibastuz coals, carried out in the colored light of glass balls of polystyrene.

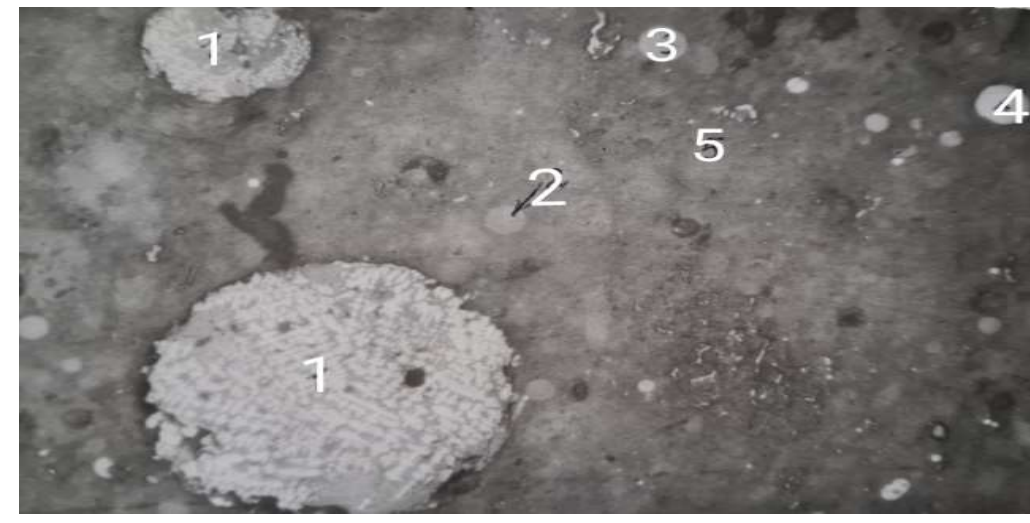

Fig.-5: Ash of Ekibastuz Coals. The light reflected, increasing 210x 1-balls with Crystallization of Magnesite; 2-

Colorless Glass Balls; 3-Yellowish-Brown Color; 4 - Black Opaque; 5-Polystyrene.

During the research, the mechanical and chemical composition of ash slag, the reaction $\mathrm{pH}$ of the medium, coal ash, as well as water-physical properties was determined.

\section{Mechanical Composition}

The basis of the features of coal ash as a medium for plant development is its solid phase, which changes under the influence of external conditions, such as weathering, temperature fluctuations, and leaching. ${ }^{12}$ The solid phase of the test sample consists of unconnected ash particles, with the inclusion of slag. Characteristics of the percentages of particles of different sizes are given in Table-3.

Analysis of Table- 3 shows that, in terms of its granulometric composition, coal ash is presented in the form of sand and dust. The ash from the Bogatyr coal mine contains more dust-like fraction (about 70\%) than the sandy one, and the ash from the Karaganda basin contains sandy material (up to $67 \%$ Karazhyra and up to $33 \%$ Maikube). Mainly ash is sandy loam.

\section{Chemical Composition of Coal Ash}

According to the chemical composition shown in Table-3, the ash of coals corresponds to alum inosilicate formations. The content of $\mathrm{SiC}>2$ in the ash of various coals varies from 40.5 to $50.3 \%$, which corresponds to its content in ordinary black soil; $\mathrm{A}_{2} \mathrm{O}_{3}$-from 12.9 to 32.4 and $\mathrm{Fe}_{2} \mathrm{O}_{3}$-from 5.5 to $17.7 \%$, which is 1.4-2.1 times higher than the content of these elements in black soil ${ }^{12}$. The amount of loss during calcination of the unburned part varies from 0.3 to $10.9 \%$, depending on the amount of unburned coal dust and carbonates in the ash. The particles of unburned coal dust present in the ash are potential humus, are 
RASĀYAN J. Chem.

Vol. 14 | No. 2 |1208-1215| April - June | 2021

closely related to ash silicates, and, undergoing slow physicochemical and biochemical transformations, play a small role in the formation of ash fertility ${ }^{15-21}$. Mobile potassium $\left(\mathrm{K}_{2} \mathrm{O}\right)$ contains from 1.6 to 25.0 $\mathrm{mg} / 100 \mathrm{~g}$ of ash, which according to the existing gradations of potassium supply is not enough for plant development. The reaction of the medium $(\mathrm{pH})$ of coal ash varies from 5.9 to 8.5, i.e. from slightly acidic to alkaline. Coal ash is an uninhabited substrate.

Spectral analysis revealed the presence of up to 30 different macro-and microelements in coal ash, including calcium, barium, manganese and iron, which are vital for plants. Therefore, coal ash can be used as micro fertilizers. Noting the content of coal ash in large quantities of aluminum, manganese, nickel and iron, the authors ${ }^{12}$ believe that this affects the growth of plants, causes them to change the color of leaves and increased the fragility of stems.

Table-3: Mechanical Composition of Coal Ash in the Karaganda Basin (Maikube, Karazhyr Deposits) and Ekibastuz Basin (Bogatyr Deposit).

\begin{tabular}{|c|c|c|c|c|c|c|c|c|c|c|c|}
\hline \multirow{4}{*}{$\begin{array}{c}\text { Sections of } \\
\text { Coal } \\
\text { Deposits }\end{array}$} & \multirow{4}{*}{ 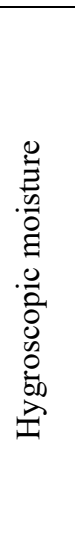 } & \multirow{4}{*}{ 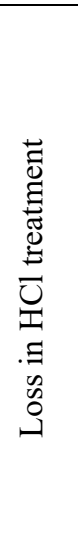 } & \multicolumn{6}{|c|}{ Number of Particles } & \multicolumn{2}{|c|}{$\begin{array}{c}\text { Sum of the } \\
\text { Fractions }\end{array}$} & \multirow{4}{*}{$\begin{array}{c}\text { The name of } \\
\text { the substrate } \\
\text { on a } \\
\text { mechanical } \\
\text { structure }\end{array}$} \\
\hline & & & \multicolumn{2}{|c|}{$\begin{array}{c}\text { Sand } \\
\text { (Diameter, } \\
\mathrm{mm} \text { ) }\end{array}$} & \multicolumn{3}{|c|}{$\begin{array}{c}\text { Dust } \\
\text { (Diameter, } \mathrm{mm} \text { ) }\end{array}$} & Silt & \multirow{2}{*}{ 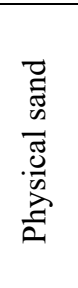 } & \multirow{2}{*}{$\begin{array}{l}\frac{\vec{J}}{0} \\
\frac{\pi}{0} \\
\frac{0}{2} \\
\frac{1}{a}\end{array}$} & \\
\hline & & & $\stackrel{\Xi}{\stackrel{\Xi}{\Xi}}$ & हี & 舫 & 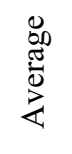 & 胥 & \multirow{2}{*}{$\begin{array}{l}\ddot{8} \\
\dot{0}\end{array}$} & & & \\
\hline & & & 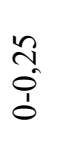 & 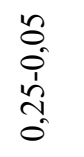 & $\begin{array}{l}0 \\
0 \\
1 \\
0 \\
0 \\
0\end{array}$ & $\begin{array}{l}n \\
8 \\
0 \\
1 \\
0 \\
0 \\
0\end{array}$ & $\begin{array}{ll}1 & - \\
8 & 0 \\
0 & 0 \\
0 & 0\end{array}$ & & $\stackrel{\overrightarrow{0}}{\dot{0}}$ & $\begin{array}{l}\ddot{0} \\
\stackrel{0}{\Lambda}\end{array}$ & \\
\hline Bogatyr & - & 19,4 & 0,5 & 4,23 & 56 & 5,4 & 9,3 & 4,9 & 60,8 & 19,6 & sandy loam \\
\hline Karazhyra & 3,05 & 13,6 & 16,2 & 50,9 & 6,8 & 3,8 & 3,7 & 4,7 & 74,0 & 12,3 & sandy loam \\
\hline Maikube & 2,04 & 30,4 & 6,15 & 26,8 & 23.5 & 1.7 & 4,6 & 6,5 & 56,8 & 12,9 & sandy loam \\
\hline
\end{tabular}

Table-4: Analysis of Water Extraction of Brown and Hard Coal Ash from Ekibastuz and Karaganda Basins, Bogatyr, Karazhyr and Maikube Sections

\begin{tabular}{c|c|c|c|c|c|c|c}
\hline \multirow{2}{*}{$\begin{array}{c}\text { Types of } \\
\text { Coals }\end{array}$} & \multirow{2}{*}{$\begin{array}{c}\text { Dense } \\
\text { Residue, } \%\end{array}$} & \multicolumn{7}{|c}{ Content (\%) of Absolutely Dry Weight } \\
\cline { 3 - 8 } & & $\mathrm{CO}_{3}$ & $\mathrm{HCO}_{3}$ & $\mathrm{Cl}$ & $\mathrm{SO}_{4}$ & $\mathrm{Ca}$ & $\mathrm{Mg}$ \\
\hline Bogatyr & 0,121 & no & 0,015 & 0,011 & 0,074 & 0,002 & 0,001 \\
\hline Karazhyra & 0,075 & no & 0,029 & 0,005 & traces & 0,009 & 0,003 \\
\hline Maikube & 0,053 & no & 0,025 & 0,004 & traces & 0,007 & 0,003 \\
\hline
\end{tabular}

\section{Thermal Mode}

Coal ash is characterized by a high albedo, which varies throughout the day. According to the study of the reflectivity of the ash of Ekibastuz coal in the ash dump, the ash has an increased albedo, as shown in Table-5. Gray-earth soils of the South of the Republic of Kazakhstan have an albedo of about 18-30\%, which indicates the dryness and light color of the surface layer of the earth.

Water-physical properties of coal ash. The specific gravity of the solid phase of ash is in the range of 2.1$2.9 \mathrm{~g} / \mathrm{cm}^{3}$, and the volume weight is low (due to the loose addition of accumulations) and ranges from 0.7 to $1.0 \mathrm{~g} / \mathrm{cm}^{3}$, which is close to the volume weight of the humus horizon of black soil (0.8-1.2), but below the volume weight of mineral horizons of $1.6 \mathrm{~g} / \mathrm{cm} 3$. Ash accumulations have a good borehole capacity (50.0-71.8\% ) and at the same time air supply (37.3-50.1\% ). The porosity or borehole of the ash is $55-65 \%$ capillary, which indicates an increased water-holding capacity of the ash. Therefore, precipitation is completely absorbed by ash, replenishing the internal moisture reserves in the ash dump thickness. This indicates that the ash of coals according to the water regime is quite suitable for growing plants and is a kind of substrate for plant development, and there are no fundamental differences between the ash of brown and hard coals in terms of water-physical and chemical properties. 
RASĀYAN J. Chem.

Vol. 14 | No. 2 |1208-1215| April - June | 2021

Table-5: Gray-earth Soils in the South of the Republic of Kazakhstan have an Albedo of about 18-30\%, which indicates dryness and light color of the surface layer of the earth

\begin{tabular}{c|c|c}
\hline Hours of Observation & The Air Temperature, $\%$ & Albedo, $\%$ \\
\hline 9 & 25 & 17,6 \\
\hline 10 & 30 & 20,0 \\
\hline 15 & 32 & 25,0 \\
\hline 16 & 36 & 29,8 \\
\hline
\end{tabular}

\section{CONCLUSION}

Analyses have established that ash and slag waste from thermal power plants and off-balance ores contain components that have unique technological properties that allow them to be effectively used as fertilizers since these macro-and microelements are urgently needed for the normal growth and development of plants. The study of the composition of coal ash cuts hero, Karagara and Maikube and chemical composition of carbonate-siliceous phosphatic dolomite raw material deposits Aksay predetermines the possibility of their use in obtaining mixed fertilizers for agriculture.

Summarizing all of the above, we can draw the following conclusions:

- The solid phase of coal ash is an unbound particle of various sizes and is a polydisperse substrate;

- The mechanical composition of the ash of various coals ranges from Sands to light coarse-grained powdery loams;

- The chemical composition of the ash corresponds to aluminosilicate formations containing (wt. \% ): $\mathrm{SiO}_{2}-40.5-60.3 ; \mathrm{AI}_{2} \mathrm{O}_{3}-12.9-32.4$ coal Ash is a non-saline substrate

- The reaction of the medium $(\mathrm{pH})$ varies from slightly acidic $(\mathrm{pH}=5.9)$ to alkaline $(\mathrm{pH}=8.5)$, which determines its suitability for the development of the forage system of plants;

- Coal ash contains a significant range of macro-and microelements, which are very necessary for plants;

- According to the temperature regime, coal ash refers to weakly heat-conducting substrates with a sharp amplitude of temperature fluctuations on the surface and in-depth that contribute to improving the water-physical properties of the soil.

\section{REFERENCES}

1. K. van Leeuwen, E. de Vries, S. Koop, K. Roest, Environmental Management, 61,786(2018), DOI: $10.1007 / \mathrm{s} 00267-018-0995$

2. N.S. Avramva, Z.I. Yakovleva. A.S. Alexander, Chemistry, p.304(2019)

3. B.A. Aldashov, V.I. Fox, A 42 Innovative Technological Chemical Processing of Karatau Phosphorites and Utilization of Phosphorus-containing Wastes, Almaty: Galym, p.248(2017).

4. V.C. Farmer «The Infrared Spectra of minerals», Mineralogical Society, 41 queen's gate. London, p.539(2016).

5. A.G. Vlasov, V.A. Florinskaya et al., "Infrared Spectra of Inorganic Glasses and Crystals", Publishing House "Chemistry", p.304(1972).

6. H. R. Minerals (600 Spectra), Thermo Fisher Scientific Inc. for Nicolet FT-IR, 2008.

7. E.I. Tsypina, Yu.A. Zabeleminsky. T.P. Unanyants ,Chemistry, p.280(2018).

8. A. Bhatt, Sh. Priyadarshini, A. Acharath, M.A. Abri, M. Sattler, S. Techapaphawit, Case Studies in Construction Materials, 11, e00486(2019), DOI:10.1016/j.cscm.2019.e00263

9. V. K. Popova, Yu. M. Posokhova, I. L. Rachevb, and A. N. Zaostrovskiic, Solid Fuel Chemistry 45,128(2011), DOI:10.3103/S0361521911020091

10. F. B. Vieira da Silva, C.W. Araújo do Nascimento, P.R. Muniz Araújo’Brazil Journal of Soil Science and Plant Nutrition, 17(3), 635(2017), DOI:10.4067/S0718-95162017000300007

11. A. A. Anarbayev, G. M. Ormanova, B.N. Kabylbekova, N.A. Vysotskaya, B.Kh. Kucharov, Rasayan Journal of Chemistry, 13(4), 2180(2020), DOI:10.31788/RJC.2020.1345888

12. N.A. Vysotskaya, B.N. Kabylbekova, K.A. Bekzhigitova, L.D. Aikozova, G.M. Adyrbekova, L.A. Zhurhabayeva and E.N. Abdulova, Rasayan Journal of Chemistry, 13(3), 1342(2020), DOI: $10.31788 /$ RJC.2020.1335841

[RJC-6344/2020] 